\title{
Soil Chemistry and Cucumber (Cucumis sativus L.) Yield as Influenced by 16 Years of Composted Poultry Litter Addition
}

\author{
Hebert D. A. Abobi ${ }^{1}$, Armand W. Koné2 ${ }^{2}$ Bernard Y. Koffi ${ }^{2}$, Saint Salomon F. Diahuissié ${ }^{3}$, Stanislas K. Loukou ${ }^{4}$ \\ $\&$ Seydou Tiho ${ }^{5}$ \\ ${ }^{1}$ UFR Agroforesterie, Université Jean Lorougnon Guédé de Daloa, Daloa, Côte d'Ivoire \\ ${ }^{2}$ UR Gestion Durable des Sols, UFR des Sciences de la Nature, Université Nangui Abrogoua, Abidjan, Côte \\ d'Ivoire \\ ${ }^{3}$ UFR Biosciences, Université Felix Houphouet-Boigny de Cocody, Abidjan, Côte d'Ivoire \\ ${ }^{4}$ Ferme Pédagogique Tshanfeto, Paroisse Saint-Bernard, Abidjan, Côte d'Ivoire \\ ${ }^{5}$ UR Ecologie et Biodiversité, UFR des Sciences de la Nature, Université Nangui Abrogoua, Abidjan, Côte \\ d'Ivoire
}

Correspondence: Hebert D. A. Abobi, UFR Agroforesterie, Université Jean Lorougnon Guédé de Daloa, BP 150 Daloa, Côte d'Ivoire. Tel: 00225-0775-0059. E-mail: hebertabobi@gmail.com

Received: October 25, 2017

doi:10.5539/jas.v10n1p325
Accepted: November 27, 2017 Online Published: December 15, 2017

URL: https://doi.org/10.5539/jas.v10n1p325

The research was financed by the Institut de Recherche pour le Développement (IRD) and the Programme d'Appui Stratégique à la Recherche Scientifique en Côte d'Ivoire (PASRES) through the project ERAfrica-ConneSSA.

\begin{abstract}
Poultry litter is increasingly used as organic amendment in market gardening in Côte d'Ivoire. To know about the sustainability of this practice, its impacts on soil quality should be known. This study aimed at assessing the effect on soil fertility of composted poultry litter addition for 16 years following two distinct ways, and identifying soil parameters driving cucumber yield. Trials were laid out in a Fisher randomized block design with 3 treatments replicated 5 times each: Control (C), Surface-applied compost (SAC) and Buried compost (BC). Soil $(0-20 \mathrm{~cm})$ chemical characteristics and cucumber growth and yield parameters were measured. Values of all parameters were higher with compost addition compared to the control, except for the $\mathrm{C}: \mathrm{N}$ ratio. SAC and BC showed similar values of organic $\mathrm{C}$, total $\mathrm{N}, \mathrm{CEC}, \mathrm{pH}$ and available phosphorus. However, $\mathrm{Ca}^{2+}, \mathrm{Mg}^{2+}, \mathrm{K}^{+}$and base saturation were higher in SAC than in BC. Relative to values in the control, the greatest changes in soil parameters were observed with exchangeable cations, followed by soil organic matter. Soil organic $\mathrm{C}$ and total $\mathrm{N}$ concentrations have doubled in SAC while $\mathrm{Ca}^{2+}, \mathrm{Mg}^{2+}$, and $\mathrm{K}^{+}$increased at greater rate $(702.4,400.9$ and $186.67 \%$ respectively). Also, cucumber growth parameters were the highest with compost addition compared to the control. Significant effect of the compost application way on cucumber was also observed: collar diameter, leaf area and fresh fruit yield in SAC $\left(0.72 \pm 0.02 \mathrm{~cm}, 258.9 \pm 12.3 \mathrm{~cm}^{2}, 11.1 \pm 1.3 \mathrm{t} \mathrm{ha}^{-1}\right.$, respectively $)$ were higher than in $\mathrm{BC}\left(0.56 \pm 0.01 \mathrm{~cm}, 230.2 \pm 2.5 \mathrm{~cm}^{2}, 5.4 \pm 0.5 \mathrm{t} \mathrm{ha}^{-1}\right.$ respectively). Fruit yields in SAC and BC were four times and twice higher than in the control $\left(2.6 \pm 0.3 \mathrm{t} \mathrm{ha}^{-1}\right)$, respectively. Cucumber growth parameters were determined by soil concentration in $\mathrm{Mg}^{2+}$ while yield was determined by $\mathrm{Ca}^{2+}$. Composted poultry litter should be promoted for a sustainable soil fertility management in vegetable farming systems.
\end{abstract}

Keywords: animal waste management, dystric ferralsol, organic agriculture, soil responsiveness, vegetable farming, Tshanfeto

\section{Introduction}

Urban and peri-urban agriculture play an important role in food security in African cities (Bricas \& Seck, 2004) where vegetable crops such as cucumber (Cucumis sativus L.) now constitute one of the main staple crops. In Côte d'Ivoire, annual cucumber production amounts approximately to 30000 tons (Sangaré et al., 2009). To increase vegetable production on overexploited soils and meet the increasing demand, market gardeners 
commonly use mineral fertilizer. However, these times, they are increasingly using local amendments such as fresh poultry litter, cow dung and other household wastes (Houndantodé, 2004). For a sustainable and effective agricultural use of these organic sources, their impacts on soil organic matter and crop yield and quality should be addressed.

Soil carbon, in the form of soil organic matter (SOM), is a key indicator for ecosystem services provided by soils both for agricultural functions (i.e. production and economy) and for environmental functions (e.g. carbon sequestration and air quality) (Kassi et al., 2017). Intensive poultry production in the peri-urban areas of Côte d'Ivoire has resulted in increased availability of poultry litter which is increasingly used as organic amendment in market gardening. Now, the need and utilization of poultry litter has overtaken the use of other animal wastes, because of its high content of nitrogen, phosphorus and potassium (Suthamathy \& Seran, 2013). However, poultry litter is essentially used fresh rather than in the composted form. Substitution of poultry litter especially its composted form for inorganic fertilizers in crop production could help overcoming inconvenients such as soil degradation and acidification, eutrophization, $\mathrm{N}_{2} \mathrm{O}$ emissions, etc.

Compost consists of the relatively stable decomposed organic materials resulting from the accelerated biological degradation under controlled aerobic conditions (Andersen et al., 2010; Villar et al, 2017). This organic material contributes to the stabilization and increase of crop productivity by exerting an equalizing effect of seasonal fluctuations regarding water, air and heat balance of soils (Adugna, 2016). Also, it promotes seed germination and plant root development (Edwards \& Hailu, 2011). Composting poultry litter addresses many problems associated with the agricultural use of fresh poultry litter, such as lowering moisture content, reducing bad odours and limiting accumulation of soluble salts which may be detrimental to plant growth (Dikinya \& Mufwanzala, 2010). This process was reported to be an effective method for reducing concentrations of organic micro-pollutants (Sadef et al., 2015). It also provides a more uniform substrate and stable carbon that promotes greater C sequestration as opposed to noncomposted poultry litter (Peltre et al., 2010; Bouajila \& Sanaa, 2011). Thus, composting could be a good option for a more sustainable agricultural system within small-scale farming in Sub Saharan Africa.

Although animal wastes have been used as manure for long times world-wide (López-Masquera et al., 2008), very few studies have focused the potential impacts of composted poultry litter on soil chemical and biological properties or on crop yield, particularly vegetables. Thus, the objective of this study was to evaluate the impact of 16 years of continuous use of this kind of compost on soil chemical attributes and cucumber growth and yield parameters considering two distinct ways of application: surface application and landfill. The study also intended to identify nutrients that determine cucumber fruit yield. The main assumptions were as follows: (i) soil fertility parameters and cucumber yield are higher with buried compost due to protection into the soil, slower mineralization and limited run-off of nutrients; (ii) accumulation of specific nutrients in soil over time will impact cucumber growth and yield.

\section{Materials and Methods}

\subsection{Site Description}

The study took place at the agricultural training center of Tshanfeto $\left(5^{\circ} 20^{\prime} 12^{\prime \prime} \mathrm{N}\right.$ and $\left.4^{\circ} 7^{\prime} 57^{\prime \prime} \mathrm{W}\right)$ located at the western outskirt of Abidjan, South of Côte d'Ivoire (Figure 1). The climate is equatorial with two rain seasons and two dry seasons. The average maximum monthly rainfall over the past 10 years was $435.78 \mathrm{~mm}$ in June and the minimum is $15.18 \mathrm{~mm}$ in January. Annual rainfall averages $1750 \mathrm{~mm}$. Monthly temperature varies from 24.2 to $27.9^{\circ} \mathrm{C}$, and hygrometry from 90 to $100 \%$. Soils are dystric ferralsols (Yao-Kouamé \& Alou, 2008) with acidity decreasing from top to down. Soil organic matter content ranges between $2 \%$ and $3 \%$.

\subsection{Experimental Design and Compost Characterization}

The experimental design was a randomized block with 5 replicates. The study included three treatments:

$>$ Control (C) with no addition of composted poultry litter;

$>$ Surface-applied compost (SAC): compost was applied at the surface of planks at the rate of $30.5 \mathrm{t} \mathrm{DM} \mathrm{ha}^{-1}$ for the whole cropping year.

> Buried compost (BC): compost was buried in $20 \mathrm{~cm} \times 20 \mathrm{~cm} \times 30 \mathrm{~cm}$ holes. Each hole was filled with $1 \mathrm{~kg}$ of dry compost for all the year. The total rate of application was $32.5 \mathrm{t} \mathrm{DM} \mathrm{ha}^{-1}$.

Poultry litter was composted in aerobic conditions. Watering and turning occurred once every two weeks to ensure good conditions for substrate decomposition. Compost reached maturity after about 10 weeks; it was harvested, dried and analyzed for chemical parameters. Values obtained were as follows: N: $15.4 \mathrm{~g} \mathrm{~kg}^{-1} ; \mathrm{P}: 6.7 \mathrm{~g}$ 
$\mathrm{kg}^{-1} ; \mathrm{K}^{+}: 2.4 \mathrm{~g} \mathrm{~kg}^{-1} ; \mathrm{Ca}^{2+}: 30.8 \mathrm{~g} \mathrm{~kg}^{-1} ; \mathrm{Mg}^{2+}: 3.1 \mathrm{~g} \mathrm{~kg}^{-1}$. Yearly quantities of nutrients supplied to soil on the different plots are displayed in Table 1 .

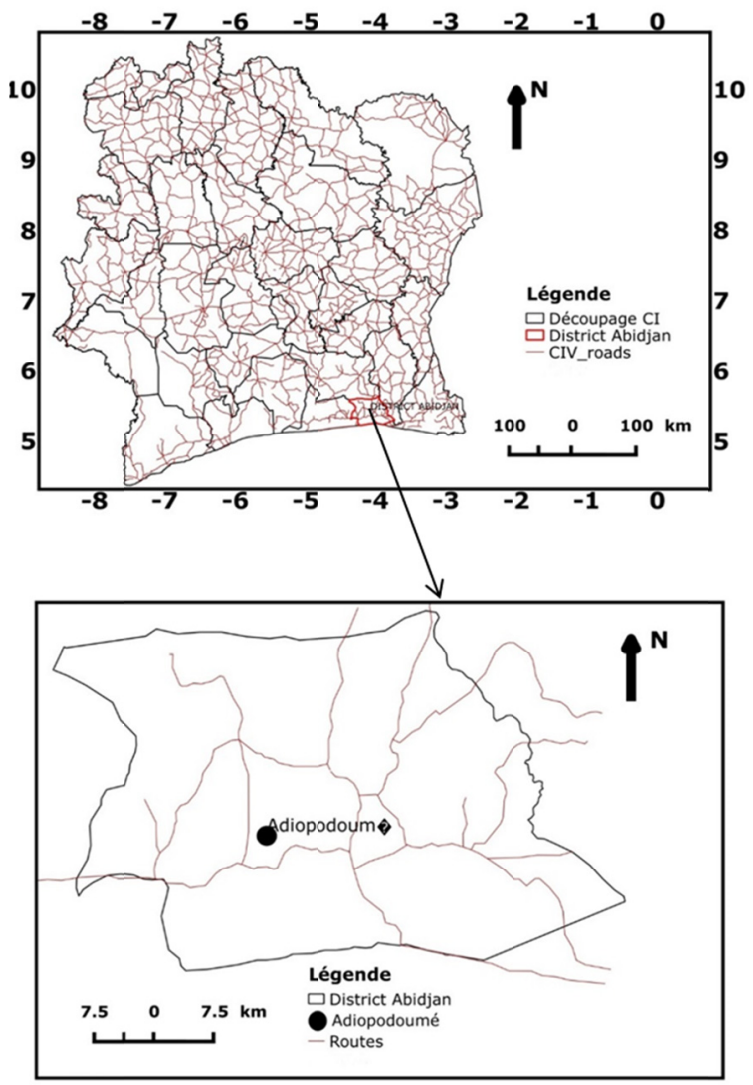

Figure 1. Map of the study site

Table 1 . Yearly quantities of nutrients provided to soil through composted poultry litter

\begin{tabular}{llllll}
\hline \multirow{2}{*}{ Treatments } & \multicolumn{5}{c}{ Quantities $\left(\mathrm{kg}^{-1} \mathrm{ha}^{-1} \mathrm{year}^{-1}\right)$} \\
\cline { 2 - 6 } & $\mathrm{N}$ & $\mathrm{P}$ & $\mathrm{Ca}^{2+}$ & $\mathrm{Mg}^{2+}$ & $\mathrm{K}^{+}$ \\
\hline SAC & 469.7 & 204.35 & 939.4 & 94.55 & 73.2 \\
BC & 500.5 & 217.75 & 1001.0 & 100.75 & 78.0 \\
\hline
\end{tabular}

Note. SAC: surface-applied compost; BC: buried compost.

\subsection{Cucumber Growth Conditions}

Composted poultry litter was tested on the cucumber variety Tokyo (50-60 days cycle). Cucumber seeds were sown ( 2 to 3 seeds per hole) at $20 \mathrm{~cm}$ spacing or a density of approximately 31,370 seed holes ha ${ }^{-1}$ on all plots. Unless rain occurred, plots were watered daily until harvest. At that time, growth parameters namely height, leaf area and collar diameter were measured on 5 randomly chosen plants on each plot. Also, fruits were counted and weighted.

\subsection{Soil Sampling and Analyses}

On each plot, soil samples were collected at the $0-20 \mathrm{~cm}$ layer at five points using an auger. For a given plot, the five samples were mixed to obtain a composite sample of which an aliquot $(1 \mathrm{~kg})$ was air-dried, $2 \mathrm{~mm}$-sieved and stored in plastic bags for further chemical analyses.

Soil $\mathrm{pH}$ was determined using a glass electrode in 1:2.5 soil:water ratio. The CEC and exchangeable cations were measured using standard methods (Anderson \& Ingram, 1993). Available phosphorus was extracted using the Bray-1 method (Olsen \& Sommers, 1982) and measured through a Technicon Autoanalyzer. Base saturation 
rate was then expressed using the $\mathrm{CEC}$ and the exchangeable cation contents. Organic $\mathrm{C}$ and total $\mathrm{N}$ concentrations were determined using the Walkley and Black (1934) and the Kjedahl methods (Bremner, 1965) respectively.

\subsection{Statistical Analyses}

Mean comparisons were done using one-way analysis of variance (ANOVA) after verification of the homogeneity of variances (Levene test). Mean separation was done using Student-Newman-Keuls test at 5\%. Multiple regressions were also used for testing the influence of soil chemical parameters on cucumber growth and yield parameters. All these tests were done using the Statistica 7.1 software. A Principal Component Analysis (PCA) was performed on the data matrix using the ADE 4 programme package (Thioulouse et al., 1997) to determine soil and cucumber parameters that best drive between-treatment discrimination. Results were considered significant when $\mathrm{p}<0.05$.

\section{Results}

\subsection{Effects of the Ways of Compost Addition on Soil Chemical Parameters}

Composted poultry litter addition significantly increased soil $\mathrm{pH}$ relative to the control (Table 2). The effect of the compost application way was also significant $(\mathrm{p}=0.04)$; value in SAC was higher than that in BC.

Compost addition over 16 years significantly increased soil organic $\mathrm{C}$ and total $\mathrm{N}$ compared with the control. However, values obtained in SAC were similar to those in $\mathrm{BC}$, suggesting that the way of compost application had no significant effect on SOM. The C:N ratio did not show any significant difference between treatments.

Available $\mathrm{P}$ also increased with compost addition $(\mathrm{p}=0.001)$. However, no significant difference was observed between SAC and BC.

Table 2. Soil acidity, organic matter and available P status [Mean(SE)]

\begin{tabular}{lllll}
\hline Soil parameters & SAC & BC & Control & Anova, $\mathrm{p}$ \\
\hline $\mathrm{pH}$ & $6.7(0.1) \mathrm{c}$ & $6.1(0.2) \mathrm{b}$ & $5.5(0.1) \mathrm{a}$ & 0.04 \\
Total $\mathrm{C}\left(\mathrm{g} \mathrm{kg}^{-1}\right)$ & $18.6(0.1) \mathrm{b}$ & $16.2(0.17) \mathrm{b}$ & $9.3(0.08) \mathrm{a}$ & 0.04 \\
Total N $\left(\mathrm{g} \mathrm{kg}^{-1}\right)$ & $1.7(0.01) \mathrm{b}$ & $1.5(0.02) \mathrm{b}$ & $0.9(0.01) \mathrm{a}$ & 0.04 \\
$\mathrm{C} / \mathrm{N}$ ratio & $10.8(0.2) \mathrm{a}$ & $10.8(0.3) \mathrm{a}$ & $10.8(0.3) \mathrm{a}$ & 0.8 \\
Available $\mathrm{P}\left(\mathrm{mg} \mathrm{kg}^{-1}\right)$ & $83.6(3.2) \mathrm{b}$ & $67.4(8.0) \mathrm{b}$ & $42.2(5.2) \mathrm{a}$ & 0.001
\end{tabular}

Note. SAC: surface-applied compost; BC: buried compost. Values with different letters are significantly different at the 0.05 level.

The CEC was higher in plots with compost addition compared to the control (Table 3) but no significant difference was observed between the two ways of addition. Exchangeable cations and base saturation increased in plots with compost addition relative to the control. Significant differences were observed between the two ways of addition, SAC stressing higher values than BC.

Increments induced in soil chemical attributes in plots where compost was added relative to the control (Table 4) were higher with SAC (22.18 to $702.43 \%)$ than BC (11.24 to 425.24\%). According to the magnitude of change, soil chemical parameters could be ranged in the order $\mathrm{Ca}>\mathrm{Mg}>\mathrm{V}>\mathrm{K}>\mathrm{C}>\mathrm{N}>\mathrm{P}>\mathrm{CEC}$, regardless of the way of compost addition.

Table 3. Characteristics of the absorbent complex [Mean(SE)]

\begin{tabular}{lllll}
\hline Soil parameters & SAC & BC & Control & Anova, $p$ \\
\hline $\mathrm{CEC}\left(\mathrm{cmol}_{\mathrm{c}} \mathrm{kg}^{-1}\right)$ & $11.3(0.4) \mathrm{b}$ & $9.7(1.0) \mathrm{b}$ & $6.3(0.2) \mathrm{a}$ & 0.03 \\
$\mathrm{Ca}^{2+}\left(\mathrm{cmol}_{\mathrm{c}} \mathrm{kg}^{-1}\right)$ & $3.3(0.1) \mathrm{c}$ & $2.2(0.3) \mathrm{b}$ & $0.4(0.01) \mathrm{a}$ & $<0.001$ \\
$\mathrm{Mg}^{2+}\left(\mathrm{cmol}_{\mathrm{c}} \mathrm{kg}^{-1}\right)$ & $1.1(0.0) \mathrm{c}$ & $0.8(0.1) \mathrm{b}$ & $0.2(0.0) \mathrm{a}$ & $<0.001$ \\
$\mathrm{~K}^{+}\left(\mathrm{cmol}_{\mathrm{c}} \mathrm{kg}^{-1}\right)$ & $0.2(0.0) \mathrm{b}$ & $0.1(0.0) \mathrm{a}$ & $0.1(0.0) \mathrm{a}$ & 0.049 \\
$\mathrm{~V}(\%)$ & $41.3(1.3) \mathrm{c}$ & $31.7(1.2) \mathrm{b}$ & $12.6(1.3) \mathrm{a}$ & $<0.001$
\end{tabular}

Note. SAC: surface-applied compost; BC: buried compost. Values with different letters are significantly different at the 0.05 level. 
Table 4 . Increments induced by composted poultry litter addition to soil over 16 years

\begin{tabular}{lcc}
\hline \multirow{2}{*}{ Soil parameters } & \multicolumn{2}{c}{ Compost-induced variation $(\%)$} \\
\cline { 2 - 3 } & $\mathrm{SAC}$ & $\mathrm{BC}$ \\
\hline $\mathrm{pH}$ & 22.18 & 11.64 \\
Total C $\left(\mathrm{g} \mathrm{kg}^{-1}\right)$ & 101.3 & 74.73 \\
Total N $\left(\mathrm{g} \mathrm{kg}^{-1}\right)$ & 100.0 & 74.42 \\
Available P $\left(\mathrm{mg} \mathrm{kg}^{-1}\right)$ & 98.1 & 59.72 \\
$\mathrm{CEC}\left(\mathrm{cmol}_{\mathrm{c}} \mathrm{kg}^{-1}\right)$ & 77.6 & 53.63 \\
$\mathrm{Ca}^{2+}\left(\mathrm{cmol}_{\mathrm{c}} \mathrm{kg}^{-1}\right)$ & 702.43 & 425.24 \\
$\mathrm{Mg}^{2+}\left(\mathrm{cmol}_{\mathrm{c}} \mathrm{kg}^{-1}\right)$ & 400.95 & 268.57 \\
$\mathrm{~K}^{+}\left(\mathrm{cmol}_{\mathrm{c}} \mathrm{kg}^{-1}\right)$ & 186.67 & 73.33 \\
\hline
\end{tabular}

Note. SAC: surface-applied compost; BC: buried compost.

\subsection{Effect of the Way of Compost Addition on Cucumber Growth and Yield Parameters}

Composted poultry litter addition strongly increased cucumber growth and yield parameters $(\mathrm{p}<0.001$ for all considered growth parameters). Seedling height was the highest in $\mathrm{BC}$ followed by $\mathrm{SAC}$, thus showing a significant effect of the way of compost application (Figure 2). The lowest height was recorded in the control. Relative to the control, BC and SAC increased seedling height by 318.02 and $236.45 \%$, respectively.

Leaf area was also significantly increased by composted poultry litter addition (Figure 3). However, no difference was observed between SAC and BC. The parameter increased by $227.7 \%$ in SAC and $191.4 \%$ in BC.

Collar diameter was significantly higher in plots where compost was added (Figure 4), the impact was stronger with surface applied compost (78.4\%) as oppopsed to buried compost (38.1\%).

Similar to growth parameters, fresh cucumber fruit yield was greatly improved by composted poultry litter addition. Yield was the highest in SAC, intermediate in BC and the lowest in the control (Figure 5). Fruit yields in SAC and BC were 4-fold and 2-fold that in the control, respectively. Moreover, yield in SAC was significantly higher than in $\mathrm{BC}$.

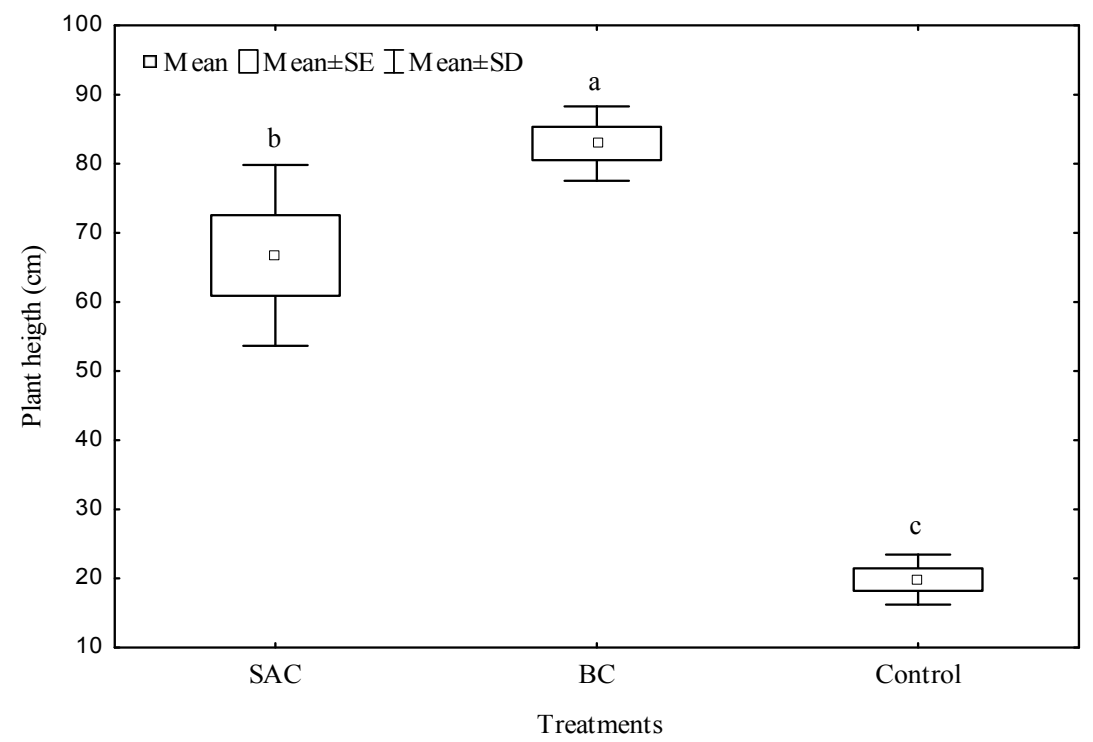

Figure 2. Cucumber liana length in the different treatments

Note. SAC: surface-applied compost; BC: buried compost. Means with different letters are significantly different at the 0.05 level. 


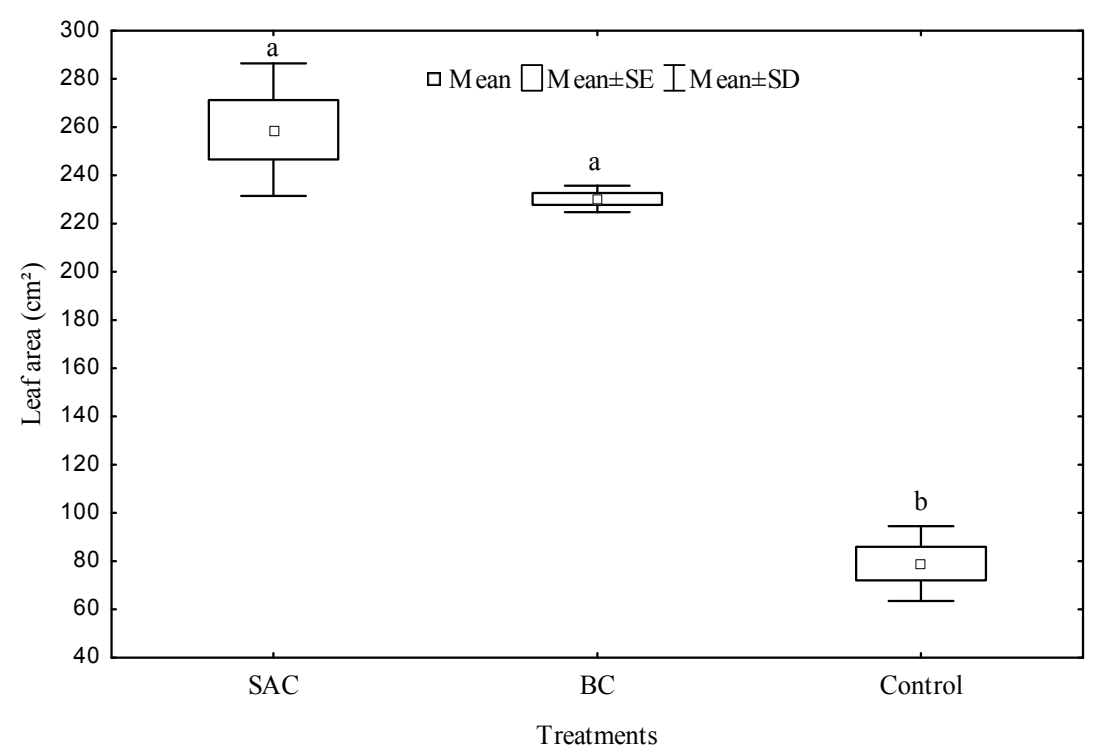

Figure 3. Cucumber leaf area in the different treatments

Note. SAC: surface-applied compost; BC: buried compost. Means with different letters are significantly different at the 0.05 level.

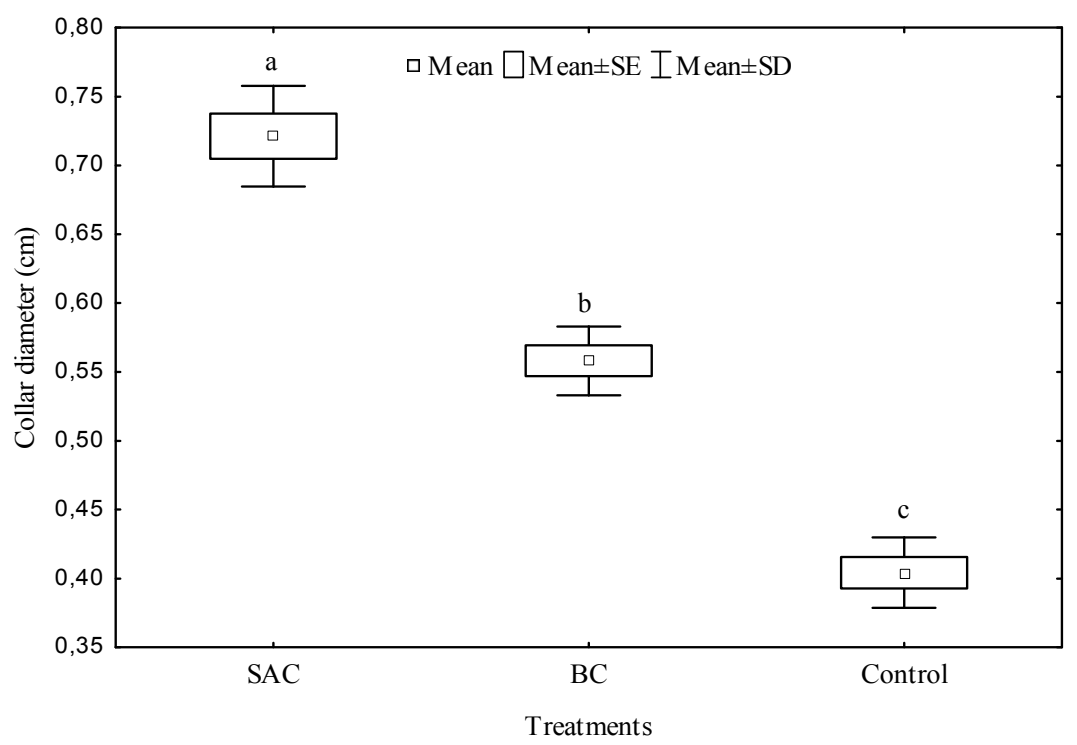

Figure 4. Cucumber collar diameter in the different treatments

Note. SAC: surface-applied compost; BC: buried compost. Means with different letters are significantly different at the 0.05 level.

Except for the liana length, the considered cucumber growth and yield parameters were significantly influenced by soil fertility parameters. Specifically, $\mathrm{Mg}^{2+}$ positively influenced leaf area $(\beta=1.2, \mathrm{p}=0.04)$ and collar diameter $(\beta=1.0, p=0.04)$. In turn, fresh fruit yield was positively influenced by $\operatorname{CEC}(\beta=3.1, p=0.04)$ and $\mathrm{Ca}^{2+}(\beta=-5.32, \mathrm{p}=0.03)$. 


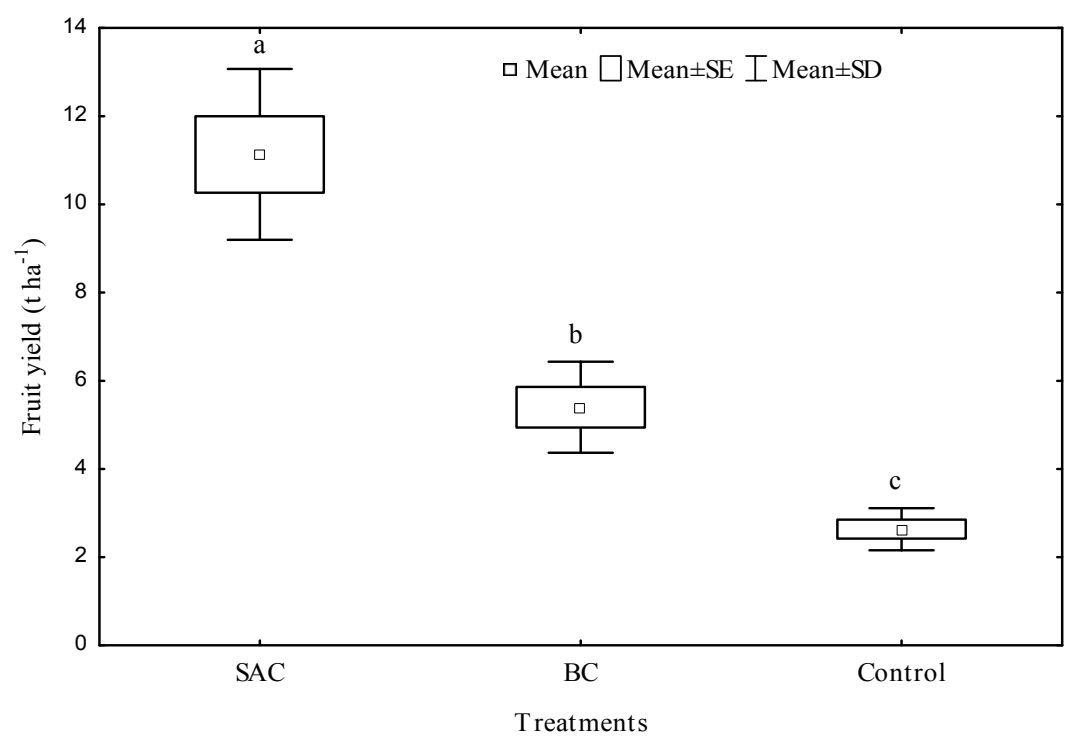

Figure 5. Cucumber fresh fruit yields in the different treatments

Note. SAC: surface-applied compost; BC: buried compost. Means with different letters are significantly different at the 0.05 level.

\subsection{Soil and Cucumber Parameters Explaining Discrimination between Treatments}

A normalized Principal Component Analysis (PCA) was performed on soil and cucumber parameters to identify those distinguishing between compost application options. The contribution of the axes 1 and 2 to variability between treatments were 77.5 and 7.6\%, respectively (Figure 6a). On the basis of the correlation between the axes and the variables, axis 1 reflects a gradient of soil chemical parameters. This axis was also linked to all the considered cucumber growth and yield parameters.

The projection of the treatments in the factorial 1-2 plane (Figure 6b) revealed three distinct plot groups primarily along the axis 1 : SAC which is characterized by the highest values of soil fertility and cucumber parameters, $\mathrm{BC}$ by intermediate values, and the control by the lowest values. 

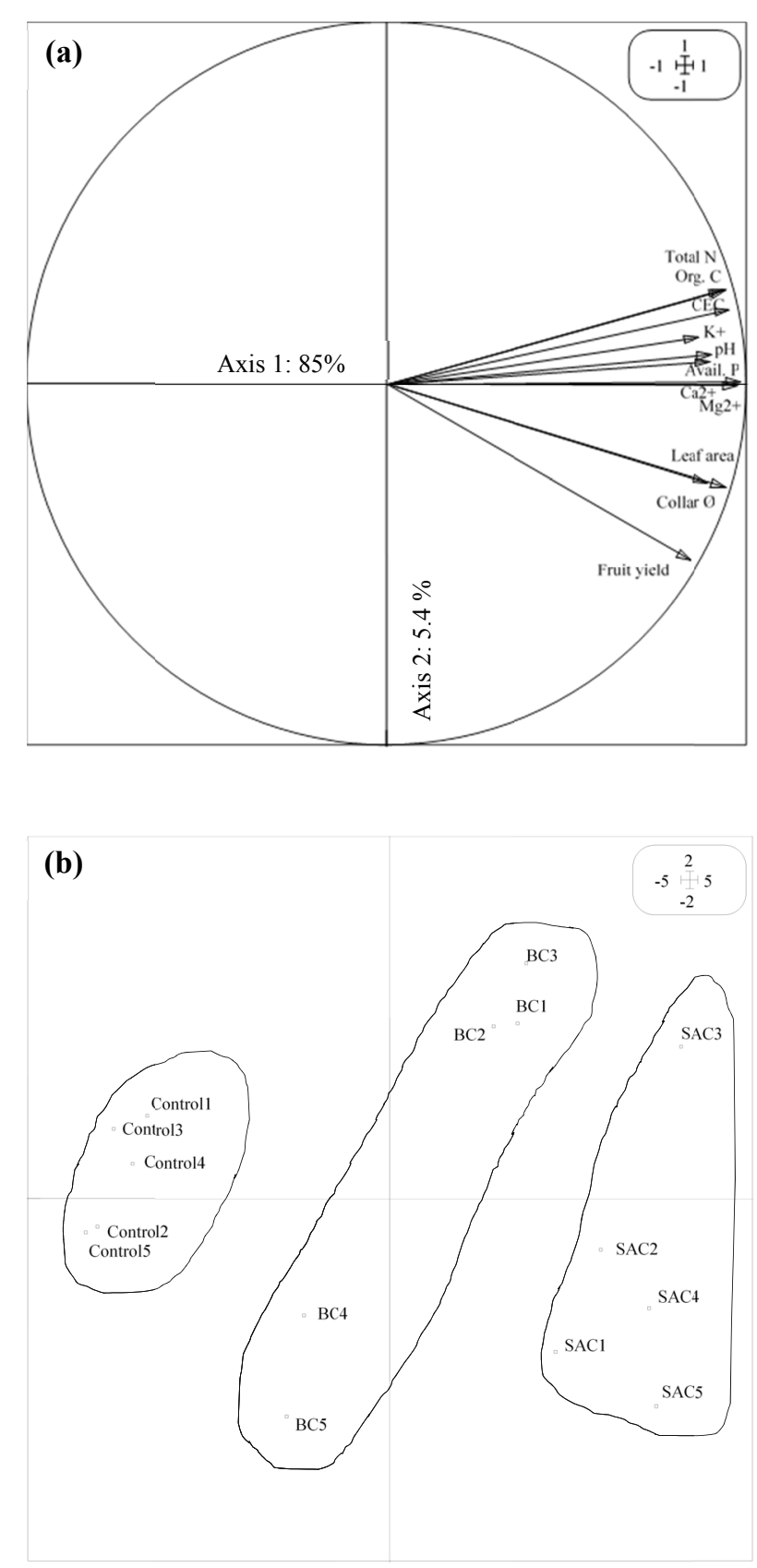

Figure 6. Normalized principal component analysis (PCA) on soil attributes and cucumber parameters: (a) correlation circle and (b) projection of plots in the factorial planes 1 and 2

\section{Discussion}

\subsection{Effect of Composted Poultry Litter on Soil Chemical Parameters}

Composting is reported to provide a more stable material which is known to enhance carbon storage in soil (Peltre et al., 2010; Alavi et al., 2017). However, the compost usage in agriculture is constrained because of its long-time action and its reduced supply of nutrients to the crops in the short run (Sánchez et al., 2017). This suggests that their beneficial effects are perceptible after a certain period of time. In the present study, 16 years of continuous application resulted in significant increase in soil $\mathrm{C}$ and nutrient concentrations in SAC and BC plots. Specifically, the trend in $\mathrm{N}$ could be explained by the fact that poultry litter was initially rich in $\mathrm{N}$ owing to the quantity of proteins incorporated into poultry food. Soil $\mathrm{C} / \mathrm{N}$ ratio in the three treatments were quasi-identical and low ( 10.8), reflecting a regular decomposition of SOM (Huber \& Schaub, 2011). This is also an indication that the potential of organic matter for mineralization is the same in the soils under the three treatments, 
suggesting no influence of the external factor nor the way of application of compost, but that of intrinsic soil characteristics.

Soil $\mathrm{pH}$ is a critical parameter for the plant mineral nutrition as it regulates nutrient availability and soil biological activity. The optimal soil $\mathrm{pH}$ was reported to be close to neutral, between 6.6 and 7.5. In the present work, addition of composted poultry litter over 16 years resulted in a rise of $\mathrm{pH}$ from 5.5 (acidic) in the control to 6.72 (near neutral) in SAC. This highlights the buffering capacity of the composted poultry litter which could be linked to the fact that exchangeable cations accumulated in the soil over years. Thus, the compost showed a liming effect as previously observed (Agegnehu et al., 2014; Alavi et al., 2017). This effect is accountable for by the noteworthy accumulation of cations such as $\mathrm{Ca}^{2+}$ and $\mathrm{Mg}^{2+}$ which are known to reduce soil acidity (Dikinya \& Mufwanzala, 2010). A hypothetical additional reason could be the buffering activity of fungi which usually develop in the organic substrates (Amlinger et al., 2007) such as compost. Djéké et al. (2011) also observed such phenomenon in soil samples amended with cocoa hull. The decrease in soil acidity greatly contributed to the improved phosphorus availability in SAC and BC (Kotchi et al., 2010; Kolawole, 2016).

The higher concentration of soil $\mathrm{Ca}^{2+}, \mathrm{Mg}^{2+}$ and $\mathrm{K}^{+}$in $\mathrm{SAC}$ as opposed to $\mathrm{BC}$ may be explained by the fact that the compost was applied at the same location for 16 years on SAC plots, while in BC the position of the holes consistently shifted from one year to the next. This difference could also be due to increased CEC in SAC which reflects an improvement of the overall adsorbent complex following long-term composted poultry litter addition (Edwards \& Hailu, 2011). The order of the increments in exchangeable cation concentrations in the present study was $\mathrm{Ca}>\mathrm{Mg}>\mathrm{K}$ which deviates a bit from the order $\mathrm{Ca}>\mathrm{K}>\mathrm{Mg}$ reported by Dikinya and Mufwanzala (2010). This difference may be explained by the fact that the authors used fresh poultry manure.

\subsection{Effect of Composted Poultry Litter on Cucumber}

In general, composted poultry litter significantly improved cucumber growth parameters as a result of improved soil fertility. Specifically, magnesium appeared to be determinant to cucumber development (increased collar diameter and leaf area). Likewise, cucumber fruit yield was positively impacted by composted poultry litter addition. Differently to growth attributes, fresh fruit yield was determined by soil calcium concentration. Although previous works reported on the beneficial impact of compost on crop productivity (Kimuni et al., 2014; Mulaji, 2011), no attention was paid to the determinant nutrient in cucumber growth and fruit production yet. Therefore, our findings deserve consideration. Data also throw light on the importance the quantities of $\mathrm{Ca}$ and $\mathrm{Mg}$ accumulated in the soil over the 16 precedent years for cucumber production.

Comparing the impact of the ways of compost addition, the higher values of cucumber collar diameter and fruit yield in SAC could be explained by the fact that the bulk of cucumber roots are superficial (FAO, 1988). Spreading compost at soil surface, cucumber roots which develops more densely in that zone more easily got access to the nutrients, resulting in improved mineral nutrition (Koffi, unpublished data). Another reason could be that cucumber roots in SAC plots were in contact with the nutrient source (compost) on a larger area as opposed to roots in $\mathrm{BC}$ plots where the nutrient source was confined in a limited area $(20 \mathrm{~cm} \times 20 \mathrm{~cm} \times 20 \mathrm{~cm}$ hole). Also, because of its high water holding capacity, compost at the soil surface in SAC plots allowed for improved water nutrition (Edwards \& Hailu, 2011) as cucumber roots are primarily superficial.

\section{Conclusion}

Long term application of composted poultry litter led to a great increase in soil fertility parameters, particularly exchangeable cations. As a result, the majority of cucumber growth parameters increased as well as fruit yield. The latter was determined primarily by soil CEC and $\mathrm{Ca}^{2+}$ concentrations. However, the positive impact of the studied compost was greater when applied at the soil surface than buried. Based on this observation, composted poultry litter should be promoted in the framework of sustainable vegetable farming.

However, further studies that focus on the quality of the poultry litter compost in terms of trace elements and its impact on soil biology should be undertaken to achieve more complete information of links with the soil ecosystem and biodiversity. Also, the mechanism of nutrient acquisition in relation with the way of application (surface application $v s$. landfill) should be investigated to get a clear understanding of its impact on cucumber growth and fruit production.

\section{Acknowledgements}

This work was carried out within the framework of the ERA-NET ERAfrica joint Call/Project ConneSSA. We are grateful to Father Hyacinthe Ali Konan, Director of the Tshanfeto agricultural training centre for allowing access to the site. 


\section{References}

Adugna, G. (2016). A review on impact of compost on soil properties, water use and crop productivity. Academic Research Journal of Agricultural Science and Research, 4, 93-104, https://doi.org/10.14662/ ARJASR2016.010

Agegnehu, G., Van Beek, C., \& Bird, M. (2014). Influence of integrated soil fertility management in wheat andtef productivity and soil chemical properties in the highland tropical environment. Journal of Soil Science and Plant Nutrition, 14, 532-545. https://doi.org/10.4067/S0718-95162014005000042

Alavi, N., Daneshpajou, M., Shirmardi, M., Goudarzi, G., Neisi, A., \& Babaei, A. A. (2017). Investigating the efficiency of co-composting and vermicomposting of vinasse with the mixture of cow manure wastes, bagasse, and natural zeolite. Waste Management, 69, 117-126. https://doi.org/10.1016/j.wasman.2017. 07.039

Amlinger, F., Peyr, S., Geszti, J., Dreher, P., Karlheinz, W., \& Nortcliff, S. (2007). Beneficial effects of compost application on fertility and productivity of soils (p. 235). Literature Study, Federal Ministry for Agriculture and Forestry, Environment and Water Management, Austria. Retrieved from https:/www.bmlfuw.gv.at/dam/jcr:0e4f3b5a-1d71.../CompBenefits\%5B1\%5D.pdf

Andersen, J. K., Christensen, T. H., \& Scheutz, C. (2010). Substitution of peat, fertiliser and manure by compost in hobby gardening: User surveys and case studies. Waste Management, 30, 2483-2489. https://doi.org/ 10.1016/j.wasman.2010.07.011

Anderson, J. M., \& Ingram, J. S. I. (1993). Tropical soil biology and fertility (A Handbook of Methods, 2nd ed.). Wallingford-CAB International. https://doi.org/10.1017/S0014479700024832

Bouajila, K., \& Sanaa, M. (2011). Effects of organic amendments on soil physico-chemical and biological properties. Journal of Materials and Environmental Science, 2, 485-490.

Bremner, J. M. (1965). Total nitrogen. In C. A. Black (Ed.), Methods of soil analysis (Part 2, pp. 1149-1176). American Society of Agronomy, Madison, USA. Retrieved from https:/www.animalsciencepublications. org/.../agronomymonogra

Bricas, N., \& Seck, P. A. (2004). L'alimentation des villes du Sud: les raisons de craindre et d'espérer. Cahiers Agricultures, 13(1), 10-14. Retrieved from https://halshs.archives-ouvertes.fr/halshs-00127819

Dikinya, O., \& Mufwanzala, N. (2010). Chicken manure-enhanced soil fertility and productivity: Effects of application rates. Journal of Soil Science and Environmental Management, 1, 46-54. Retrieved from http://www.academicjournals.org/JSSEM

Djéké, D. M., Angui, T. K. P., \& Kouadio, Y. J. (2011). Décomposition des broyats de coques de cacao dans les sols ferrallitiques de la zone d'Oumé, centre-ouest de la Côte d'Ivoire: Effets sur les caractéristiques chimiques des sols. Biotechnology, Agronomy, Society and Environment, 5, 109-117.

Edwards, S., \& Hailu, A. (2011). How to make compost and use. In L. L. Ching, S. Edwards, \& H. S. Nadia (Eds.), Climate change and food systems resilience in Sub-Saharan Africa (pp. 379-436). FAO, Italy.

FAO. (1988). Cultures protégées en climat méditerranéen (p. 317). Rome. Retrieved from http://www.iamm. ciheam.org/ress_doc/opac_css/index.php

Houndantodé, Z. J. (2004). Influence des boues résiduaires sur les caractéristiques physico-chimiques des sols sableux du sud-Bénin: cas de la commune de Sèmè-Podji (Master thesis, Université d'Abomey-Calavy, Bénin).

Huber, G., \& Schaub, C. (2011). La fertilité des sols: L'importance de la matière organique. Guide des amendements organiques. Service Environnement-Innovation; BAS-RHIN.

Kassi, S. P. A. Y., Koné, A. W., Tondoh, J. E., \& Koffi, B. Y. (2017). Chromolaena odorata fallow-cropping cycles maintain soil carbon stocks and yam yield 40 years after conversion of native- to farm-land implications for forest conservation. Agriculture, Ecosystems and Environment, 247, 298-307. https://doi.org/10.1016/j.agee.2017.06.044

Kimuni, N. L., Mwali, K. M., Mulembo, M. T., Lwalaba, W. L. J., Lubobo, K. A., Katombe, N. B., ... Baboy L. L. (2014). Effets de doses croissantes des composts de fumiers de poules sur le rendement de chou de Chine installé sur un sol acide de Lubumbashi. Journal of Applied Biosciences, 77, 6509-6522. https://doi.org/10.4314/jab.v77i1.4 
Kolawole, G. O. (2016). Nutrient release patterns of tithonia compost and poultry manure in three dominant soils in the southern guinea savanna, Nigeria. International Journal of Plant \& Soil Science, 10, 1-8. https://doi.org/10.9734/IJPSS/2016/25828

Kotchi, V., Yao, K. A., \& Sitapha, D. (2010). Réponse de cinq variétés de riz à l'apport de phosphate naturel de Tilmesi (Mali) sur les sols acides de la région forestière de Man (Côte d'Ivoire). Journal of Applied Biosciences, 31, 1895-1905. Retrieved from http://www.biosciences.elewa.org

López-Masquera, M. E., Cabaleiro, F., Sainz, M. S., López-Fabal, A., \& Carral, E. (2008). Fertilizing value of broiler litter: Effects of drying and pelletizing. Bioresource Technology, 99, 5626-5633. https://doi.org/ 10.1016/j.biortech.2007.10.034

Mulaji, M. (2010). Utilisation des composts de bio-déchets ménagers pour l'amélioration de la fertilité des sols acides de la province de Kinshasa (République Démocratique du Congo) ( $\mathrm{PhD}$ dissertation, Université de Liège, Gembloux).

Olsen, S. R., \& Sommers, L. E. (1982). Phosphorus. In A. L. Page, R. H. Miller \& D. K. Keeny (Eds.), Methods of soil analysis (2nd ed., Part 2, pp. 403-430). America Society of Agronomy, Madison, USA. Retrieved from http://www.scirp.org/.../reference/ReferencesPapers.aspx?ReferenceID

Peltre, C., Dignac, M. F., Derenne, S., \& Houot, S. (2010). Change of the chemical composition and biodegradability of the Van Soest soluble fraction during composting: A study using a novel extraction method. Waste Management, 30, 2448-2460. https://doi.org/10.1016/j.wasman.2010.06.021

Sadef, Y., Poulsen, T. G., \& Bester, K. (2015). Impact of compost process conditions on organic micro pollutant degradation during full scale composting. Waste Management, 40, 31-37. https://doi.org/10.1016/j.wasman. 2015.03.003

Sánchez, Ó. J., Ospina, D. A., \& Montoya, S. (2017). Compost supplementation with nutrients and microorganisms in composting process. Waste Management, 69, 136-153. https://doi.org/10.1016/ j.wasman.2017.08.012

Sangaré, A., Koffi, E. M., Akamou, F., \& Fall, C. A. (2009). État des ressources phytogénétiques pour l'alimentation et l'agriculture: Second rapport national (p. 65). Abidjan, Côte d'Ivoire, MINAGRI/FAO. Retrieved from http://www.fao.org/docrep/014/i1500f/i1500f.pdf

Suthamathy, N., \& Seran, T. H. (2013). Residual effect of organic manure EM Bokashi applied to preceding crop of vegetable cowpea (Vigna unguiculata) on succeeding crop of radish (Raphanus sativus). Research Journal of Agriculture and Forestry Sciences, 1, 2-5.

Thioulouse, J., Chessel, G., Dolédec, S., \& Olivier, J. M. (1997). ADE-4: A multivariate analysis and graphical display software. Statistics and Computing, 7, 75-83. https://doi.org/10.1023/A:1018513530268

Villar, I., Alves, D., \& Mato, S. (2017). Product quality and microbial dynamics during vermicomposting and maturation of compost from pig manure. Waste Management, 69, 498-507. https://doi.org/10.1016/ j.wasman.2017.08.031

Walkley, A., \& Black, I. A. (1934). An examination of the Degtjareff method for determining soil organic matter, and a proposed modification of the chromic acid titration method. Soil Science, 34, 29-38. https://doi.org/ 10.1097/00010694-193401000-00003

Yao-Kouamé, A., \& Alou, K. R. (2008). Propriétés du sol et domestication de Lippia multiflora (Verbenaceae) en Côte d'Ivoire. Agronomie Africaine, 20, 97-107. Retrieved from https://www.ajol.info/index.php/aga/ article/download/1739/637

\section{Copyrights}

Copyright for this article is retained by the author(s), with first publication rights granted to the journal.

This is an open-access article distributed under the terms and conditions of the Creative Commons Attribution license (http://creativecommons.org/licenses/by/4.0/). 